\title{
Kajian Ekonomis PLT-Angin dan PLTS untuk Penerangan Jalan Umum (PJU)
}

\author{
Erick Radwitya $^{1)}$, Akhdiyatul ${ }^{2)}$ \\ ${ }^{1,2)}$ Magister Teknik Elektro, Fakultas Teknik Universitas Tanjungpura Pontianak, \\ ${ }^{1,2}$ Staf Pengajar Program Studi Teknik Elektro, Politeknik Negeri Ketapang. \\ e-mail : erickradwitya@gmail.com, ariendhya@gmail.com
}

\begin{abstract}
Kabupaten Ketapang merupakan Kabupaten terluas, memiliki pantai yang memanjang dari selatan ke utara dan sebagian besar penduduk tinggal di pesisir pantai, dengan kecepatan angin rata-rata adalah $5,1 \mathrm{~m} / \mathrm{s}$ dan persentase penyinaran matahari $70 \%$ merupakan yang tertinggi di Kalimantan Barat. Jika dilihat dari letak dan iklim, untuk memenuhi kebutuhan energi listrik dalam memenuhi kebebutuhan PJU di Kabupaten Ketapang. Salah satu solusi untuk memenuhi kebutuhan energi yang diperlukan PJU adalah Energi Angin dan Energi Surya. Guna mengoptimalkan potensi energi terbarukan yaitu energi angin dan energi surya yang ada di Kabupaten Ketapang untuk kebutuhan PJU maka perlu suatu Kajian Ekonomis Pembangkit Listrik Tenaga Angin Stand Alone dan Pembangkit Listrik Tenaga Surya Stand Alone untuk PJU. Analisis ekonomi adalah suatu analisis untuk mengetahui layak tidaknya suatu kegiatan untuk dilaksanakan dan titik beratnya pada hasil total, produktivitas dan keuntungan. Dalam analisis finansial ini biasanya digunakan Cost Benefit Analisys, Capital Recovery, Payback of Period, Break Even Point dan Benefit Cost Ratio. Hasil yang diperoleh dari kajian ini, untuk PLT Angin AWI-E500T biaya investasi awal senilai Rp. 41.688 .350 dengan kapasitas produksi $723 \mathrm{kWh}$ per tahun dan biaya investasi awal untuk PLTS Solar Cell senilai Rp. 18.625.800 dengan kapasitas produksi 204,4 kWh per tahun. Dari analisis ekonomi dengan menggunakan metode BCR, hasil nilai Benefit Cost Ratio untuk PLT Angin AWI E500T dan PLTS Solar Cell lebih besar dari $1(B C R \geq 1)$, ini berarti investasi layak (feasible) untuk dilaksanakan.
\end{abstract}

Keywords-PLT-Angin Stand Alone, PLTS Solar Cell Stand Alone, Penerangan Jalan Umum (PJU), dan Benefit Cost Ratio (BCR)

\section{Pendahuluan ${ }^{[16][17][22]}$}

Kabupaten Ketapang merupakan salah satu Kabupaten yang berada di Propinsi Kalimantan Barat, terletak di antara garis $0^{\circ} 19^{\prime} 00^{\prime \prime}-3^{\circ} 05^{\prime} 00^{\prime \prime}$ Lintang Selatan dan $108^{\circ} 42^{\prime} 00^{\prime \prime}-111^{\circ} 16^{\prime} 00^{\prime \prime}$ Bujur Timur. Dibandingkan Kabupaten lain di Kalimantan Barat, Kabupaten Ketapang merupakan Kabupaten terluas, memiliki pantai yang memanjang dari selatan ke utara dan sebagian besar penduduk tinggal di pesisir pantai, sedangkan daerah hulu umumnya berupa daratan yang berbukit - bukit dan diantaranya masih merupakan hutan. Di lihat berdasarkan iklim, Kabupaten Ketapang ber iklim tropis dengan suhu rata - rata $23,70^{\circ} \mathrm{C}-26,70^{\circ} \mathrm{C}$ dan suhu pada siang hari mencapai $30,80^{\circ} \mathrm{C}$ serta memiliki curah hujan rata - rata $3696,1 \mathrm{~mm} /$ th dengan curah hujan rata - rata per tahun sebanyak 214 kali, sedangkan kecepatan angin adalah 17,25 knot dan merupakan yang tertinggi di Kalimantan Barat.

Jika dilihat dari letak dan iklim, untuk memenuhi kebutuhan energi listrik dalam memenuhi kebutuhan PJU di Kabupaten Ketapang. Salah satu solusi yang menjadi menarik untuk memenuhi kebutuhan energi listik yang diperlukan PJU adalah Energi Angin dan Energi Surya. Guna mengoptimalkan potensi energi terbarukan yaitu energi angin dan energi surya yang ada di Kabupaten Ketapang untuk kebutuhan operasional PJU maka perlu suatu Kajian Ekonomis Pembangkit Listrik Tenaga Angin Stand Alone dan Pembangkit Listrik Tenaga Surya Stand Alone untuk operasional PJU.

\section{Tinjauan Pustaka ${ }^{[3][5][6][7[8][12][19]}$ \\ 2.1. Kajian Pustaka}

Kajian potensi energi angin dan energi surya untuk penerangan jalan umum (PJU) sebelumnya sudah dilakukan beberapa peneliti-peniliti diatas dengan ruang lingkup pemanfaatan tenaga angin laut untuk memutar turbin angin vertikal jenis H-Darrieus yang ditujukan untuk memenuhi kebutuhan penerangan di jembatan Suramadu dengan kapasitas beban $79 \mathrm{~kW}$ menggunakan jenis lampu high pressure sodium (HPS) dengan masingmasing daya 250 watt (Suramadu, 2009), Perbedaan material antara PJU solar cell dengan PJU konvensional,menyebabkan perbedaan pada sisi teknis (kenyamanan) dan ekonomis (kehematan), resiko investasi pembangunan dan pengembangan Pembangkit Listrik Tenaga Angin di Nusa Penida. Penelitian pada kajian yang akan dilakukan adalah kajian analisis tenaga angin dan tenaga surya terhadap energi yang dibangkitkan dengan maksud dan tujuan untuk memenuhi kebutuhan listrik lampu penerangan jalan umum (PJU) serta analisis ekonomi biaya investasi yang dikeluarkan dengan hasil yang diperoleh dari investasi PLT-Angin stand alone dan PLTS stand alone di Kabupaten Ketapang. 


\subsection{Penerangan Jalan Umum ${ }^{[2][4][10][18][19]}$}

Jalan adalah prasarana transportasi darat yang meliputi segala bagian jalan, termasuk bangunan pelengkap dan perlengkapannya yang diperuntukkan bagi lalu lintas,yang berada pada permukaan tanah, diatas permukaan tanah, dibawah permukaan tanah atau air,serta di atas permukaan air, kecuali jalan kereta api, jalan lori, dan jalan kabel. Lampu penerangan jalan adalah bagian dari bangunan pelengkap jalan yang dapat dipasang di kiriatau kanan jalan sertadi tengah(di bagian median jalan). Fungsi lampu penerangan jalan pada umum nya adalah menerangi jalan maupun lingkungan disekitar jalan yang diperlukan termasuk persimpangan jalan (intersection), jalan layang (interchange, overpass, flyover), jembatan dan jalan di bawah tanah (underpass, terowongan).

Lampu penerangan yang dimaksud adalah suatu unit lengkap yang terdiri dari sumber cahaya (lampu/luminer), elemen-elemen optic ( pemantul /reflector, pembias / refractor, penyebar / diffuser). Elemen-elemen elektrik (konektor ke sumber tenaga /power supply dan lain-lain), struktur penopang yang terdiri dari lengan penopang, tiang penopang vertikal dan pondasi tiang lampu. Muhaimin(2001) menguraikan bahwa konsep mendasar dari merancang sebuah sistem penerangan adalah menentukan jarak tiang penerangan. Dalam menentukan jarak tiang factor pemakaian dan factor kehilangan sangat berpengaruh. Faktor kehilangan cahaya adalah faktorfactor yang menyebabkan menurunnya kualitas pencahayaan pada suatu bidang sehingga mempengaruhi kualitas dari penerangan itu sendiri. Muhaimin dalam bukunya yang berjudul teknologi pencahayaan menyatakan bahwa dalam mencari interval lampu penerangan jalan harus mempertimbangkan faktor kehilangan cahaya.

\subsection{Pembangkit Listrik Tenaga Angin (Stand Alone $)^{[1]}$}

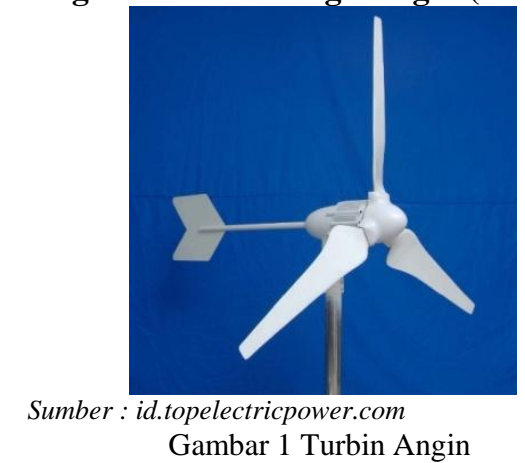

Gambar 1 menunjukkan prototype PLT-Angin, dengan prototip etersebut dapat diketahui sketsa, tata letak dan instrument yang terdiri dari bagian-bagian penting pembangkit listrik tenaga angin. Ada beberapa komponen utama dan pendukung dari PLT-Angin seperti yang ditunjukkan pada Gambar 1 diatas adalah sebagai berikut:

$\checkmark$ rotor

$\checkmark$ rangka kepala dan pengarah angin

$\checkmark$ generator

$\checkmark$ pengatur tegangan/arus

$\checkmark$ penyimpanan energi (baterai)

$\checkmark$ konverter/inverter

\subsection{Pembangkit Listrik Tenaga Surya}

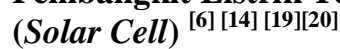

Energi listrik dapat dibangkitkan dengan mengubah sinar matahari melalui sebuah proses yang dinamakan photovoltaic (PV). Photo merujuk kepada cahaya dan voltaic merujuk kepada tegangan. Terminologi ini digunakan untuk menjelaskan selelektronik yang memproduksi energy listrik arus searah dari energy radian matahari. Photovoltaiccell dibuat dari material semikonduktor terutama silicon yang dilapisi oleh bahan tambahan khusus. Jika cahaya matahari mencapai cell maka electron akan terlepas dari atom silicon dan mengalir membentuk sirkuit listrik sehinga energy listrik dapatdi bangkitkan. Sel surya selalu didesain untuk mengubah cahaya menjadi energy listrik sebanyakbanyaknya dan dapat digabung secara seri atau paralel untuk menghasilkan tegangan dan arus yang diinginkan seperti yang dinyatakan oleh (John Wiley:2004).Unjuk kerja dari photovoltaic cell sangat tergantung kepada sinar matahari yang diterimanya. Kondisi iklim (misal awan dan kabut) mempunyai efek yang signifikan terhadap jumlah energy matahari yang diterima sel sehingga akan mempengaruhi pula unjuk kerjanya seperti dibuktikan dalam penelitian (Youness dkk, 2005)

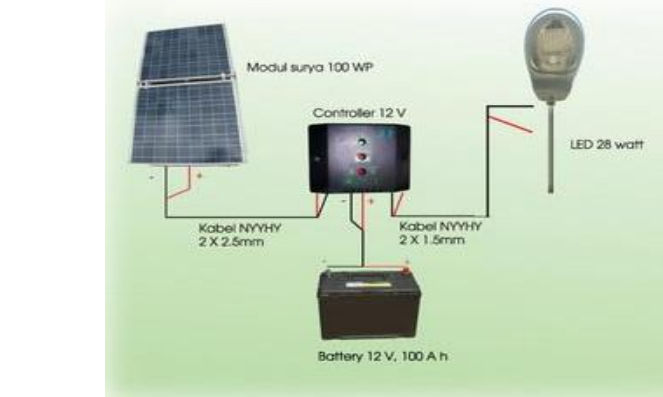

Sumber :kusumayogo, 2017

Gambar 2 Konfigurasi Dasar Sistem Penerangan Lampu Jalan Solar Cell

\subsection{Analisis Ekonomi Teknik ${ }^{[1][3][7][9][13]}$ \\ 2.6.1. CapitalRecovery $\operatorname{Cost}(\mathrm{CR})$}

Capital Recovery $\operatorname{Cost}(C R)$ dari suatu investasi adalah deret seragam dari modal yang tertanam dalam suatu investasi selama umur dari investasi tersebut. NilaiCR bisa digunakan untuk melihat apakah suatu investasi akan memberikan pendapatan yang cukup untuk menutupi modalyang dikeluarkan termasuk bunga yang mestinya dihasilkan pada tingkat MARR selama umur dari investasi tersebut. Nilai sisa dalam suatu perhitungan $C R$ dianggap sebagai pendapatan sehingga formulasi pemulihan modal $(C R)$ dapat dinyatakan sebagai berikut:

$C R=($ biaya investasi awal $)+($ biaya pemeliharaan $)-$

(nilai sisa)

Atau,

$C R_{(i)}=P_{W}\left(A_{W} / P_{W}, i \%, N\right)+A_{W}-$

$F_{W}\left(A_{W} / P_{W}, i \%, N\right)(2)$

Dimana:

$C R_{(i)}=$ ongkos pemulihan pada MARR sebesar $i \%$

$P_{W}=$ modal yang ditanamkan sebagai investasi awal

$F_{W}=$ estimasi nilai sisa pada tahun ke $N$ 
$N=$ estimasi umur investasi ditetapkan

\subsubsection{Metode Periode Pengembanlian (Payback Period)}

Pada dasarnya periode pengembalian (Payback Period) adalah jumlah periode (tahun) yang diperlukan untuk mengembalikan (menutup) ongkos investasi awal dengan tingkat pengembaliantertentu. Perhitungannya dilakukan berdasarkan alirankas baik tahunan maupun yang merupakan nilai sisa. Untuk mendapatkan periode pengembalian pada suatu tingkat pengembalian (rate of return) tertentu digunakan model formula berikut:

$0=-P_{W}+\sum_{t=0}^{N^{\prime}} A_{W t}\left(P_{W} / F_{W}, i \%, t\right)$

Dimana,

$A_{W t} \quad=$ aliran kas yang terjadi pada periode $t$

$N \quad=$ periode pengembalian yang akan dihitung

Apabila $A w$ sama dari satu periode keperiode yang lain (deretseragam) maka persamaan dapat dinyatakan berdasarkan factor $P_{W} / A_{W}$ adalah :

$0=-P_{W}+\sum_{t=0}^{N^{\prime}} A_{W t}\left(P_{W} / A_{W}, i \%, t\right)(4)$

Apabila suatu alternatif memiliki masa pakai ekonomis lebih besar dariperiode pengembalian $\mathrm{N}$ maka alternatif tersebut layak diterima. Sebaliknya,bila $\mathrm{N}$ lebih besar dari estimasi masa pakai suatu alat atau umur suatu investasimaka investasi atau alat tersebut tidak layak diterima karena tidak akan cukupwaktu untuk mengembalikan modal yang dipakai sebagai biaya awal dariinvestasi tersebut.

\subsubsection{Analisis Titik Impas (BEP)}

Pada pembahasan ini menggunakan aplikasi analisis titik impas (break even point $=B E P$ ) untuk menentukan berapa tahun waktu yang dibutuhkan (berapa ongkos atau tariff yang harus dikeluarkan atau dijua l)agar kinerja PLT-Angin pada titik impas.

Permasalahan produksi energi listrik suatu PLTAngin biasanya digunakan untuk menentukan ongkos, tarif dan tingkat produksi energi listrik yang bisa mengakibatkan perusahaan berada pada kondisi impas. Untuk mendapatkan titik impas ini maka harus dicari fungsi-fungsi biaya maupun pendapatannya. Pada saat kedua fungsi tersebut bertemu maka total biaya sama dengan total pendapatan.

Ada tiga komponen biaya yang dipertimbangkan dalam analisis ini yaitu:

a) Biaya tetap (fixedcost) yaitu biaya yang besarnya tidak dipengaruhi oleh volume produksi. Beberapa yang termasuk biaya tetap adalah biaya gedung, biaya tanah, biaya mesin dan peralatan pendukung lainya dan sebagainya.

b) Biaya variable (variable lcost) yaitu biaya yang besarnya tergantung (biasanya secara linier) terhadap volume produksi. Biaya yang tergolong biaya variabel diantaranya adalah biaya bahan baku, biaya perawatan dan biaya operasional.

c) Biaya total (total cost) adalah jumlah dan biaya tetap dan biaya variabel.

\subsubsection{Benefit Cost Ratio (BCR)}

Metode ini merupakan salah satu metode yang digunakan dalam tahap-tahap awal perencanaan investasi atau sebagai analisis tambahan dalam rangka memvalidasi hasil evaluasi yang telah digunakan sebelumnya (Giatman, 2005:79). Rumus umum:

$\mathrm{BCR}=\frac{\mathrm{PWB}}{\mathrm{PWC}}$

$$
\text { dimana: }
$$

$\mathrm{PWB}=$ present worth of benefit (keuntungan)

$\mathrm{PWC}=$ present worth of cost $($ biaya/pengeluaran $)$

Jika, PWB / PWC $\geq 1$ maka investasi proyek dinyatakan layak (feasible), dan sebaliknya jika PWB / PWC $<1$ maka investasi proyek dinyatakan tidak layak (unfeasible).

Menurut Giatman (2005), metode Benefit Cost Ratio $(B C R)$ merupakan metode yang sangat baik dilakukan untuk memvalidasi proyek-proyek Pemerintah yang berdampak langsung pada masyarakat banyak (public government project), dampak yang dimaksud baik yang bersifat positif maupun yang bersifat negatif. Metode BCR ini memberikan penekanan terhadap nilai perbandingan antara aspek r(3usfaat (benefit) yang akan diperoleh dengan aspek biaya dan kerugian yang akan ditanggung (cost) dengan adanya investasi tersebut.

\subsection{Data Kecepatan Angin dan Penyinaran Matahari $^{[21]}$}

\subsubsection{Hasil Pengukuran Data BMG}

Dari hasil pengukuran BMG kecepatan rata-rata angin di Kabupaten Ketapang sebesar 5,129228 m/s per tahun, data kecepatan angin dan persentase penyinaran matahari dari BMG Ketapang dapat dilihat pada tabel 1 dan tabel2

\begin{tabular}{|c|c|}
\hline Bulan & $\begin{array}{c}\text { Kecepatan Angin Rata-rat } \\
\qquad(\mathrm{m} / \mathrm{s})\end{array}$ \\
\hline Januari & 5,8912 \\
\hline Februari & 4,3644 \\
\hline Maret & 4,2317 \\
\hline April & 4,0491 \\
\hline Mei & 4,7793 \\
\hline Juni & 5,0781 \\
\hline Juli & 6,4388 \\
\hline Agustus & 6,4222 \\
\hline September & 5,9409 \\
\hline Oktober & 5,3601 \\
\hline Nopember & 4,3478 \\
\hline Desember & 4,6465 \\
\hline Rata-rata & 5,1292 \\
\hline \multicolumn{2}{|c|}{ Tabel2 Persentase Rata-rata Penyinaran Matahari } \\
\hline Bulan & $\begin{array}{c}\text { Penyinaran Matahari } \\
(\%)\end{array}$ \\
\hline Januari & 67 \\
\hline Februari & 79 \\
\hline Maret & 57 \\
\hline April & 63 \\
\hline Mei & 67 \\
\hline Juni & 79 \\
\hline Juli & 90 \\
\hline Agustus & 77 \\
\hline September & 85 \\
\hline Oktober & 64 \\
\hline Nopember & 64 \\
\hline Desember & 51 \\
\hline Rata-rata & 70 \\
\hline
\end{tabular}




\subsubsection{Wilayah Kabupaten Ketapang}

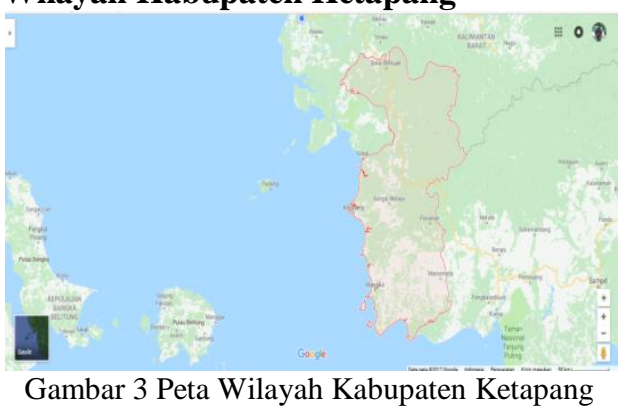

\subsubsection{Spesifikasi Turbin Angin}

Pada penelitian ini, analisa dilakukan dengan menggunakan spesifikasi teknis turbin angin tipe $\boldsymbol{A} \boldsymbol{W I}$ E500T 500W MICRO WIND TURBINE buatan Jepang. Spesifikasi turbin angin AWI-E500T dapat dilihat pada tabel 3

\begin{tabular}{ccc}
\multicolumn{2}{c}{ Tabel 3 Spesifikasi Turbin Angin AWI-E500T } \\
\hline $\begin{array}{c}\text { Permulaan Kecepatan } \\
\text { Angin }\end{array}$ & $:$ & $1 \mathrm{~m} / \mathrm{s}$ \\
\hline Kecepatan Pasang & $:$ & $1.0-1.5 \mathrm{~m} / \mathrm{s}$ \\
\hline $\begin{array}{c}\text { Kecepatan Angin } \\
\text { Pengisian }\end{array}$ & $:$ & $1.5-2.5 \mathrm{~m} / \mathrm{s}$ \\
\hline Daya & $:$ & $500 \mathrm{~W}$ \\
\hline Nilai Kecepatan Angin & $:$ & $12.5 \mathrm{~m} / \mathrm{s}$ \\
\hline $\begin{array}{c}\text { Bertahan pada kecepatan } \\
\text { angin }\end{array}$ & $:$ & $60 \mathrm{~m} / \mathrm{s}$ \\
\hline Keluaran Maksimum & $:$ & $800 \mathrm{~W}$ at $16 \mathrm{~m} / \mathrm{s}$ (generator \\
& $:$ & Elektromagnetic Braking \\
Sistem Pengereman & & System \\
\hline Berat & $:$ & $17.5 \mathrm{~kg}$ \\
\hline Diameter Rotor & $:$ & 1558 mm \\
\hline Generator & $:$ & Three phase permanent \\
& & magnet inner rotor coreless \\
generator
\end{tabular}

\subsubsection{Spesifikasi PLTS Solar Cell}

Tabel 4 Spesifikasi PLTS Solar Cell

Lampu PJU LED $30 \mathrm{~W}$ (DC); $\geq 100 \mathrm{~lm} /$ watt

\begin{tabular}{cc}
\hline Baterai & $12 \mathrm{v} 100 \mathrm{AH} ;$ Deep Cycle VRLA \\
\hline Panel Surya & $100 \mathrm{Wp}$ (Mono/Poly cristallyne) \\
\hline $\begin{array}{c}\text { BCR } \\
\text { (Controller) }\end{array}$ & PWM 20A, 12/24V \\
\hline Tiang & \pm 7 meter; Hot Deep Galvanized
\end{tabular}

Aksesoris Kabel, mounting panel, kotak baterai, angkur dan anti panjat.

\section{Hasil dan Analisis Ekonomi ${ }^{[1][13][15]}$}

3.1. Analisis Ekonomi

Analisis ekonimis yang mengarah perhitungan untuk menentukan biaya maupun tarif produksi energi per unit (per kWh) dikenal sebagai ekonomi pembangkitan
energi.Secara umum analisis ekonomi teknik digunakan sebagai analisis ekonomis dari suatu investasi seperti suatu PLT- Angin dan PLTS untuk menghitung biaya produksi energi listrik tarif dan sebagainya. Dalam analisis ekonomi dari suatu investasi suatu PLT-Angin dan PLTS memerlukan kajian yang membutuhkan data aspek teknis dan aspek kinerja ekonomi suatu aset investasi. Untuk bisa melakukan evaluasi kinerja ekonomi dibutuhkan seperti sebagai berikut:

a. Biaya tetap (fixed cost)

Biaya tetap (fixed cost) berupa estimasi biaya investasi yang terdiri dari biaya pembelian Turbin Angin AWIE500T 500Watt dan PLTS Solar biaya pembangunan tower turbin dan solar cell serta biaya pendukung lainnya.

b. Biaya tidak tetap (variable cost)

Biaya tidak tetap (variable cost) berupa biaya perawatan tahunan terdiri dari biaya operasional berupa biaya untuk penggantian baterai yang dilakukan setiap 5(lima) tahun dan biaya perawatan lainnya.

Estimasi penetapan biaya perawatan dan operasional tahunan secara keseluruhan untuk PLT-Angin merujuk pada estimasi yang direkomendasikan Assosiasi Energi Angin Eropa (EWEA) sebesar 0,025 atau 2,5\% dari biaya investasi (fixed cost) dan PLTS sebesar 0,01 atau $1 \%$ dari biaya investasi (fixed cost).

c. Estimasi lamanya sistem bisa beroperasi (umur ekonomis)

Demikian juga untuk estimasi masa pakai sistem PLTAngin dan PLTS bisa beroperasi (umur ekonomis) merujuk pada estimasi yang direkomendasikan Assosiasi Energi Angin Eropa selama antara 15 - 20 tahun.

d. Estimasi nilai sisa PLT-Angin

Estimasi nilai sisa suatu PLT-Angin merupakan nilai jual saat akhir sistem PLT-Angin tersebut dilakukan penggantian baru atau masa habis pakai, dalam hal ini diperkirakan masa pakai PLT-Angin dengan menggunakan Turbin Angin AWI-E500T 500Watt adalah 20 tahun dan penggantian baterai setiap 5(lima) tahun.

e. Tarif dan nilai jual produksi energi listrik

Untuk nilai jual produksi energi rata-rata nominal tahunan adalah besar energi rata-rata yang diproduksi dikalikan tarif jual energi per kWh berdasarkan Peraturan Menteri ESDM No.19 Tahun 2016 yaitu PLT-Angin \$ 11 sen dan PLTS Solar Cell \$ 17 sen dengan \$ 1 sama dengan Rp.13.500.

f. Estimasi tingkat pengembalian minimum yang diinginkan (MARR)

Tingkat bunga yang dipakai patokan dasar dalam mengevaluasi dan membandingkan berbagai alternatif dinamakan MARR (Minimum Attractive Rate of Return). MARR ini adalah nilai minimal dan tingkat pengembalian atau bunga yang bisa diterima.

\subsection{Rincian Biaya PLT-Angin AWI-E500T}

Estimasi perhitungan nilai sekarang $(P W)$, nilai deret seragam $(A W)$ dan nilai akan datang / nilai sisa $(F W)$ dari biaya tetap (fixed cost), biaya tidak tetap (variable cost), nilai sisa (salvage value) dan nilai jual produksi energi dari PLTAngin AWI-E500T 500Watt dengan masa pakai 20 tahun dan tingkat suku bunga (MARR) $10 \%$ per tahun serta tarif 
energi listrik PLT-Angin Rp 1.485 per kWh dan PLTS Solar Cell Rp 2.295 per kWh.

Tabel 5 Rincian biaya PLT-Angin AWI-E500T

\begin{tabular}{ccc}
\hline No & Komponen Biaya & Biaya (Rp) \\
\hline 1 & Biaya Tetap (FixedCost) & 41.688 .350 \\
\cline { 2 - 3 } & $\begin{array}{c}\text { Harga Turbin Angin AWI- } \\
\text { E500T 500Watt }\end{array}$ & 22.264 .750 \\
\cline { 2 - 2 } & $\begin{array}{c}\text { Biaya Pengiriman dari Jepan- } \\
\text { Ketapang 17,5 Kg }\end{array}$ & 6.739 .600 \\
\hline Baterai 100 Ah & 3.980 .500 \\
\hline Lampu LED 30 Watt & 3.150 .000 \\
\hline $\begin{array}{c}\text { Tiang Lampu t=9 M } \\
\text { Oktagonal }\end{array}$ & 2.363 .500 \\
\hline Box Panel & 1.440 .000 \\
\hline Biaya Instalasi & 1.000 .000 \\
\hline $\begin{array}{c}\text { Biaya Pemasangan dan } \\
\text { Pondasi Tiang Dll. }\end{array}$ & 750.000 \\
\hline
\end{tabular}

\subsection{Rincian Biaya PLTS Solar Cell}

Tabel 6 Rincian biaya PLTS Solar Cell

\begin{tabular}{ccc}
\hline No & Komponen Biaya & Biaya (Rp) \\
\hline 1 & Biaya Tetap (FixedCost) & 18.625 .800 \\
\cline { 2 - 3 } & Solar Cell 100 Wp/12 V DC & 4.257 .000 \\
\hline Solar Charge Controller & 1.684 .800 \\
\hline Baterai 100 Ah & 3.980 .500 \\
\hline Lampu LED 30 Watt & 3.150 .000 \\
\hline Tiang Lampu t=9 M & 2.363 .500 \\
Oktagonal & \\
\hline Box Panel & 1.440 .000 \\
\hline Biaya Instalasi & 1.000 .000 \\
\hline Biaya Pemasangan dan & 750.000 \\
Pondasi Tiang Dll. & \\
\hline
\end{tabular}

3.4. Hasil Perhitungan Nilai Sekarang $\left(P_{w}\right)$, Nilai Deret Seragam $\left(A_{w}\right)$ dan Nilai Akan Datang $\left(F_{w}\right)$ dari Komponen Biaya PLT-Angin dan PLTS.

Tabel 7 Besar Biaya Tetap, Biaya Tidak Tetap dan Nilai Sisa dari Komponen Biaya PLT-Angin.

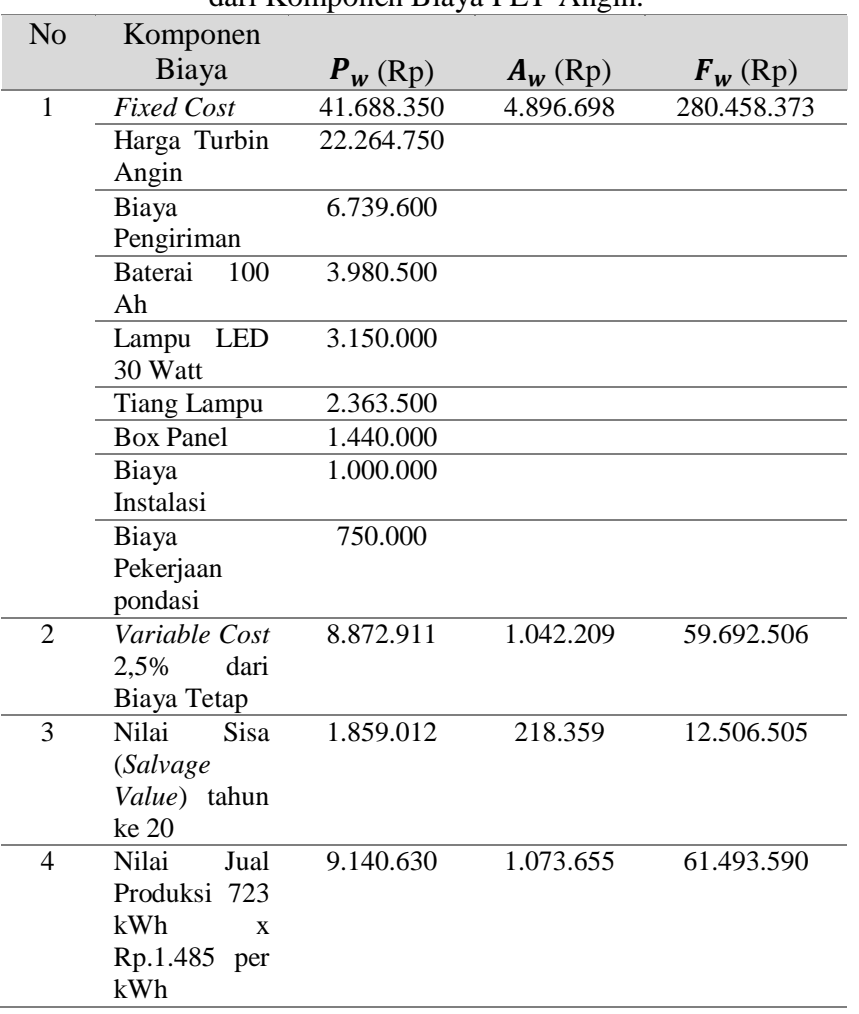

Tabel 8 Besar Biaya Tetap, Biaya Tidak Tetap dan Nilai Sisa dari Komponen Biaya PLTS Solar Cell.

\begin{tabular}{|c|c|c|c|c|}
\hline No & $\begin{array}{c}\text { Komponen } \\
\text { Biaya }\end{array}$ & $\boldsymbol{P}_{\boldsymbol{w}}(\mathrm{Rp})$ & $\boldsymbol{A}_{\boldsymbol{w}}(\mathrm{Rp})$ & $\boldsymbol{F}_{\boldsymbol{w}}(\mathrm{Rp})$ \\
\hline \multirow[t]{9}{*}{1} & Fixed Cost & 18.625 .800 & 2.187 .779 & 125.305 .069 \\
\hline & $\begin{array}{l}\text { Solar Cell } \\
100 \mathrm{Wp} / 12 \\
\text { V DC }\end{array}$ & 4.257 .000 & & \\
\hline & $\begin{array}{l}\text { Solar } \\
\text { Charge } \\
\text { Controller }\end{array}$ & 1.684 .800 & & \\
\hline & $\begin{array}{l}\text { Baterai } 100 \\
\text { Ah }\end{array}$ & 3.980 .500 & & \\
\hline & $\begin{array}{ll}\text { Lampu } \\
\text { LED } \\
\text { Watt }\end{array}$ & 3.150 .000 & & \\
\hline & $\begin{array}{l}\text { Tiang } \\
\text { Lampu } \mathrm{t}=9 \\
\mathrm{M} \\
\text { Oktagonal }\end{array}$ & 2.363 .500 & & \\
\hline & Box Panel & 1.440 .000 & & \\
\hline & $\begin{array}{l}\text { Biaya } \\
\text { Instalasi }\end{array}$ & 1.000 .000 & & \\
\hline & $\begin{array}{l}\text { Biaya } \\
\text { Pekerjaan } \\
\text { Pondasi }\end{array}$ & 750.000 & & \\
\hline 2 & $\begin{array}{l}\text { Variable } \\
\text { Cost 2,5\% } \\
\text { dari Biaya } \\
\text { Tetap }\end{array}$ & 1.585 .719 & 186.258 & 10.667 .927 \\
\hline 3 & $\begin{array}{l}\text { Nilai Sisa } \\
\text { (Salvage } \\
\text { Value) } \\
\text { tahun ke } 20\end{array}$ & 830.582 & 97.560 & 5.587 .740 \\
\hline 4 & $\begin{array}{l}\text { Nilai Jual } \\
\text { Produksi } \\
204,4 \mathrm{kWh} \\
\text { x Rp.2.295 } \\
\text { per kWh }\end{array}$ & 3.993 .696 & 469.098 & 26.867 .588 \\
\hline
\end{tabular}

\subsection{Pemulihan Modal (Capital Recovery)}

CapitalRecoveryCost $(C R)$ dari suatu investasi adalah deret seragam dari modal yang tertanam dalam suatu investasi selama umur dari investasi tersebut. Dalam kasus ini dimana perhitungan pemulihan modal (capital recovery) digunakauntuk melihat apakah masing- masing investasi PLT-Angin AWI-E500T 500Watt dan PLTSakan memberikan pendapatan yang cukup untuk menutupi modal yang dikeluarkan.

\section{a) Menggunakan PLT-Angin}

Biaya investasi awal $=\mathrm{Pw}(\mathrm{Aw} / \mathrm{Pw}, \mathrm{i} \%, \mathrm{~N})$

$$
\begin{aligned}
& =\operatorname{Pw} \times \frac{i(1+i)^{N}}{(1+i) N-1} \\
& =41.688 .350 \times\left[\frac{0,1}{(1,1)^{20}-1}\right] \\
& =\operatorname{Rp} 4.896 .698
\end{aligned}
$$

Biaya Pemeliharaan $=2,5 \% \mathrm{x}$ biaya investasi $=2,5 \%$ x Rp. 41.688 .350

$=\operatorname{Rp} 1.042 .209$

Nilai sisa $=\mathrm{Fw}(\mathrm{Aw} / \mathrm{Fw}, \mathrm{i} \%, \mathrm{~N})$

$$
\begin{aligned}
& =12.506 .505 \times \frac{i}{(1+i) N-1} \\
& =12.506 .505 \times\left[\frac{0,1}{(1,1)^{20}-1}\right] \\
& =\operatorname{Rp} 218.359
\end{aligned}
$$


pemulihan modal (capitalrecovery)atau pendapatan tahunan dapat diperoleh sebagai berikut:

$\mathrm{CR}_{(\mathrm{i})}=\mathrm{Pw}(\mathrm{Aw} / \mathrm{Pw}, \mathrm{i} \%, \mathrm{~N})+\mathrm{Aw}-\mathrm{Fw}(\mathrm{Aw} / \mathrm{Fw}, \mathrm{i} \%, \mathrm{~N})$

$=\mathrm{Rp} 41.688 .350+\mathrm{Rp} 1.042 .209-\mathrm{Rp} 12.506 .505$

$=\operatorname{Rp} 5.720 .548$

\section{b) Menggunakan PLTS}

Biaya investasi awal $=\mathrm{Pw}(\mathrm{Aw} / \mathrm{Pw}, \mathrm{i} \%, \mathrm{~N})$

$$
=\operatorname{Pw} \times \frac{i(1+i)^{N}}{(1+i) N-1}
$$$$
=\text { Rp. } 18.625 .800 \times\left[\frac{0,1}{(1,1)^{20}-1}\right]
$$

$=\operatorname{Rp} 2.187 .779$

Biaya Pemeliharaan $=1 \% \mathrm{x}$ biaya investasi $=1 \%$ x Rp. 18.625 .800

$=\operatorname{Rp} 186.258$

Nilai sisa $=\mathrm{Fw}(\mathrm{Aw} / \mathrm{Fw}, \mathrm{i} \%, \mathrm{~N})$

$=\operatorname{Rp} .5 .587 .740 \times \frac{i}{(1+i) N-1}$

$=\operatorname{Rp} 5.587 .740 \times\left[\frac{0,1}{(1,1)^{20}-1}\right]$

$=\operatorname{Rp} 97.560$

pemulihan modal (capitalrecovery)atau pendapatan tahunan dapat diperoleh sebagai berikut:

$\mathrm{CR}_{(\mathrm{i})}=\mathrm{Pw}(\mathrm{Aw} / \mathrm{Pw}, \mathrm{i} \%, \mathrm{~N})+\mathrm{Aw}-\mathrm{Fw}(\mathrm{Aw} / \mathrm{Fw}, \mathrm{i} \%, \mathrm{~N})$

$=\operatorname{Rp} 2.187 .779+\operatorname{Rp} 186.258-\operatorname{Rp} 97.560$

$=\operatorname{Rp} 2.276 .478$

Hasilperhitunganpemulihanmodal(capitalrecovery)d enganumuratau masapakaiinvestasiPLT-Angindan PLTS selama20tahundengantingkatsukubunga (MARR) $10 \%$.

\subsection{Periode Pengembalian (Payback Period)}

Pada dasarnya periode pengembalian (payback period) adalah jumlah periode (tahun) yang diperlukan untuk mengembalikan (menutup) ongkos investasi awal dengan tingkat pengembalian tertentu.

Nilai pengembalian aset pada tahun ke 20 dengan analisa perhitungan periode pengembalian (Payback Periode) untuk PLT-Angin AWI E500T 500Watt dengan tarif per kWh Rp 1.485 dan PLTS Solar Cell dengan tarif per kWh Rp 2.295 dan tingkat suku bunga (MARR) $10 \%$ per tahun dapat dilihat pada tabel 9.

Tabel 9 Nilai pengembalian pada tahun ke 20

\begin{tabular}{|c|c|c|c|c|c|c|}
\hline $\begin{array}{c}\text { Th } \\
\text { ke N }\end{array}$ & $\begin{array}{l}\text { Sumber } \\
\text { Energi }\end{array}$ & $\begin{array}{c}\text { Biaya } \\
\text { Investasi } \\
/ P w(\mathrm{Rp})\end{array}$ & $\begin{array}{c}\text { Biaya } \\
\text { Per awatan/ } \\
A_{w} \\
A w \\
(P w / A w . i \% \\
N) \\
(\mathrm{Rp})\end{array}$ & $\begin{array}{c}\text { Nilai } \\
\text { Sisa/ } \\
A_{w} \\
F w(A w / \\
F w i \% \text { - } \\
N) \\
(\mathrm{Rp})\end{array}$ & $\begin{array}{l}\text { Nilai } \\
\text { Jual } \\
\text { Energi } \\
/ A_{w} \\
(\mathrm{Rp})\end{array}$ & $\begin{array}{c}\text { Nilai } \\
\text { Pengembali } \\
\text { an } \\
\text { (Rp) }\end{array}$ \\
\hline A & B & $\mathrm{C}$ & $\mathrm{D}$ & $\mathrm{E}$ & $\mathrm{F}$ & G \\
\hline 20 & $\begin{array}{l}\text { PLT- } \\
\text { Angin }\end{array}$ & 41.688 .350 & 4.896 .698 & 218.359 & $\begin{array}{c}1.073 .65 \\
5\end{array}$ & $\begin{array}{c}(39.561 .618 \\
, 07)\end{array}$ \\
\hline 20 & PLTS & 18.625 .800 & 2.187 .779 & 97.560 & 469.098 & $\begin{array}{c}(15.387 .241 \\
, 69)\end{array}$ \\
\hline
\end{tabular}

Dengan analisa periode pengembalian (payback period) yang diperlihatkan pada Tabel 9 diatas, menunjukkan bahwa masing-masing investasi PLT-Angin dan PLTS dengan tingkat suku bunga (MARR) $10 \%$ per tahun dan asumsi tarif jual produksi enegi Rp 1.485 dan Rp. 2.295 belum mampu mengembalikan (menutup) ongkos investasi awal dengan tingkat pengembalian sampai periode/tahun ke 20 .

\subsection{Analisis Titik Impas (Break Even Point)}

Pada pembahasan ini aplikasi analisis titik impas (break even point $=B E P$ ) adalah untuk menentukan berapa tarif minimal produksi energi setiap $\mathrm{kWh}$ yang harus dijual agar kinerja PLT-Angin dan PLTS akan mencapai kondisi impas pada akhir masa pakai 20 tahun dengan tingkat suku bunga (MARR) $10 \%$. Ada beberapa komponen biaya yang dipertimbangkan dalam analisis titik

impas diantaranya :

Biaya tetap (fixed cost) berupa biaya mesin PLTAngindan PLTS besertaperalatan pendukung lainnya seperti: biaya bangunan dan lahan dirubah menjadi deret seragam adalah:

$\mathrm{FC}=$ biaya awal $\mathrm{x}\left(A_{w} / P_{w}, \mathrm{i} \%, N\right)$

PLT-Angin

FC Angin = biaya awal $\mathrm{x}\left(A_{w} / P_{w}, \mathrm{i} \%, N\right)$

$$
\begin{aligned}
& =41.688 .350 \times \frac{i(1+i)^{N}}{(1+i)^{N}-1} \\
& =41.688 .350 \times \frac{0,1(1+0,1)^{20}}{(1+0,1)^{20}-1} \\
& =\text { Rp. 4.896.698 }
\end{aligned}
$$

PLTS

$$
\begin{aligned}
\text { FC Surya } & =\text { biaya awal } \times\left(A_{w} / P_{w}, \mathrm{i} \%, N\right) \\
= & 18.625 .800 \times \frac{i(1+i)^{N}}{(1+i)^{N}-1} \\
= & 18.625 .800 \times \frac{0,1(1+0,1)^{20}}{(1+0,1)^{20}-1} \\
= & \text { Rp. } 2.187 .779
\end{aligned}
$$

Biaya variabel (variabel cost) seperti bahan baku, biaya perawatan dan biayaoperasional adalah:

$\mathrm{VC}=$ biaya perawatan tahunan $(2,5 \%$ dari biaya investasi)

PLT-Angin

VC Angin $=2,5 \% \times 41.688 .350$

$$
\text { = Rp. 1.042.209 }
$$

investasi)

$\mathrm{VC}=$ biaya perawatan tahunan $(1 \%$ dari biaya

PLTS

VC Surya $=1 \% \times 18.625 .800$ $=$ Rp. 186.258

Biaya total (total cost) merupakan jumlah dari biaya tetap dan biaya variabel adalah sebagai berikut:

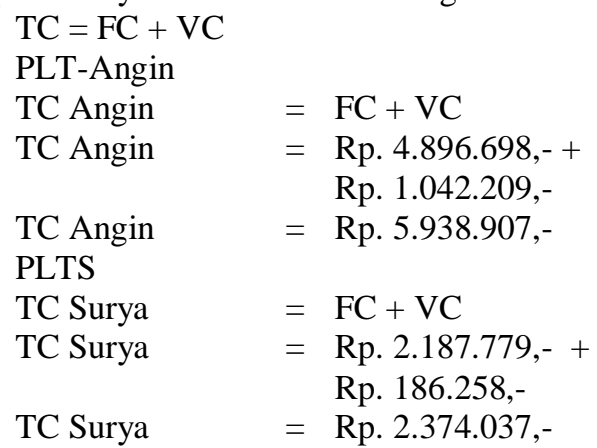

Nilai sisa, merupakan nilai jual di tahun/periode penggunaan komponen tersebut yaitu $10 \%$ dari nilai investasi awal.

$\mathrm{NS}=10 \% \mathrm{x}$ Investasi Awal PLT-Angin 


$$
\begin{aligned}
\mathrm{NS} & =10 \% \times \text { Investasi Awal } \times\left(A_{w} / F_{w}, \mathrm{i} \%, N\right) \\
& =10 \% \times 41.688 .350 \times \frac{i}{(1+i)^{N}-1} \\
& =10 \% \times 41.688 .350 \times \frac{0,1}{(1+0,1)^{20}-1} \\
& =\text { Rp. } 218.359
\end{aligned}
$$

$$
\begin{aligned}
\text { PLTS } & \\
\text { NS } & 10 \% \times \text { Investasi Awal } \times\left(A_{w} / F_{w}, \mathrm{i} \%, N\right) \\
& =10 \% \times 18.625 .800 \times \frac{i}{(1+i)^{N}-1} \\
& =10 \% \times 18.625 .800 \times \frac{0,1}{(1+0,1)^{20}-1} \\
& =\text { Rp. } 97.560
\end{aligned}
$$

Total pendapatan (total revenue) merupakan jumlah nilai jual produksi energi listrik tahunan dan nilai sisa dari PLT-Angin dan PLTS adalah:

$\mathrm{TR}=\operatorname{tr} \mathrm{X}+$ nilai sisa

Titik impas akan diperoleh apabila total ongkos/biaya persis sama dengan total pendapatan. Dalam kasus ini adalah mencari tarif yang diberikan untuk energi yang dihasilkan sehingga mendapatkan titik impas di umur periode pemakaian yaitu 20 tahun. Hasil dari perhitungan di peroleh sebagai berikut:

$0=$ Biaya Total - Total Pendapatan PLT-Angin

$0=$ Biaya Total - Total Pendapatan

$0=$ Rp. 5.938.907 $-($ tarif $x$ Kwh per tahun + Nilai sisa)

Tarif $=($ Rp. 5.938.907 - Rp. 218.359) $/ 723$

Tarif $=$ Rp. 7.912

PLTS

$0=$ Biaya Total - Total Pendapatan

$0=$ Rp. 2.374.037 $-($ tarif $x$ Kwh per tahun + Nilai sisa)

Tarif $=($ Rp. 2.374.037 - Rp. 97.560) $/ 204,4$

Tarif $=$ Rp. 11.137

Dari hasil perhitungan dapat ditentukan tarif minimal produksi energi per $\mathrm{kWh}$ pada PLT-Angin dan PLTS agar terjadi Titik Impas (BEP). Berdasarkan nilai tarif minimal produksi energi per $\mathrm{kWh}$ agar terjadi kondisi impas (BEP) pada akhir masa pakai 20 tahun dan tingkat suku bunga (MARR) $10 \%$ per tahun adalah PLTAngin Rp. 7.912 dan PLTS Rp. 11.137.

\subsection{Benefit Cost Ratio (B/C)}

$$
\mathrm{BCR}=\frac{\mathrm{PWB}}{\mathrm{PWC}}
$$

PLT-Angin

Diketahui :

PWB/ Nilai Jual Energi per Tahun (Keuntungan) = Rp. 1.073.655

PWC/ Biaya Perawatan per Tahun (Pengeluaran)= Rp. 1.042.209

$$
\begin{aligned}
\text { Jadi, BCR } & =\frac{\text { PWB }}{\text { PWC }} \\
& =\frac{\text { Rp. 1.073.655 }}{\text { Rp. 1.042.209 }} \\
=1,030172698 &
\end{aligned}
$$

\section{PLTS}

Diketahui

PWB/ Nilai Jual Energi per Tahun (Keuntungan) $=\mathrm{Rp}$. 347.480
PWC/ Biaya Perawatan per Tahun (Pengeluaran $)=\mathrm{Rp}$. 186.258

$$
\begin{aligned}
\text { Jadi, BCR } & =\frac{\text { PWB }}{\text { PWC }} \\
& =\frac{\text { Rp. } 347.480}{\text { Rp. } 186.258}
\end{aligned}
$$

$=2,518538801$

Dari hasil perhitungan didapat BCR untuk PLT-Angin 1,030172698 dan PLTS 2,518538801. Ini berarti investasi proyek PLT-Angin dan PLTS Solar Cell dapat dikatakan layak (feasible) dan dapat dilaksanakan karena nilai $\mathrm{BCR}>1$.

\section{Kesimpulan}

1. Dari hasil pembahasan pada Kajian Ekonomis PLTAngin AWI-E500T dan PLTS Solar Cell diketahui bahwa Nilai Benefit Cost Ratio (BCR) adalah lebih besar dari $1(\mathrm{BCR} \geq 1)$, dengan Feed in Tariff agar terjadi kondisi impas / Break Even Point (BEP) pada akhir masa pakai 20 tahun adalah Rp. 7.912 untuk PLT-Angin AWI-E500T dan Rp. 11.137 untuk PLTS Solar Cell.

2. Sebagai bahan pertimbangan dalam menentukan sumber energi untuk memenuhi kebutuhan energi listrik pada lampu penerangan jalan umum di daerah pesisir Kabupaten Ketapang. PLT-Angin AWI-E500T layak untuk dicoba pelaksanaan pembangunannya karena daya yang dihasilkan lebih besar dari PLTS Solar Cell.

\section{Referensi}

[1] Abdul Kadir, Energi Sumber Daya, Inovasi, Tenaga Listrik dan Potensi Ekonomi, Edisi ke dua tahun 1995, Penerbit Universitas Indonesia, Jakarta;

[2] Badan Standarisasi Nasional, 2008. SNI 7391 SpesifikasiPenerangan Jalan di KawasanPerkotaan,Jakarta:BSN;Bambang Purnomo, Kajian Potensi Energi Angin Untuk Pembangkit Listrik di Kota Pontianak, Tugas Akhir, Fakultas Teknik Jurusan Teknik Elektro Universitas Tanjungpura, Pontianak, 2008;

[3] Direktorat Jenderal Bina Marga, 1991. Spesifikasi LampuPenerangan Jalan Perkotaan, Jakarta.

[4] Daniel Bimbingan Limbong, Perbandingan Teknis dan Ekonomis Penggunaan Penerangan Lampu Jalan Solar Cell dengan Penerangan Jalan Umum Konvensional, Penelitian, Fakultas Teknik, Konsentrasi Teknik Energi Listrik, Universitas Sumatera Utara, Vol. 8 No. 3, September 2014;

[5] Engga Kusumayogo., (2013). Analisis Teknis dan Ekonomis Penerapan Penerangan Lampu Jalan Umum Solar Cell untuk Kebutuhan Penerangan di jalan Tol Darmo Surabaya, Malang: Universitas Brawijaya Malang;

[6] Erlansyah, Kajian Potensi dan Analisa Ekonomis Pembangkit Listrik Tenaga Angin Sebagai Energi Alternatif, Tugas Akhir, Fakultas Teknik Jurusan Teknik Elektro Universitas Tanjungpura, Pontianak, 2010;

[7] Ganda Akbar Rizkyan, Studi Pembangkit Listrik Tenaga Angin Laut Untuk Memenuhi Kebutuhan Penerangan Jembatan Suramadu, Tugas Akhir, Fakultas Teknik, Jurusan 
Teknik Sistem Perkapalan, Institut Teknologi Surabaya, Surabaya, 2016;

[8] Giatman. (2005). Ekonomi Teknik. Jakarta:Raja gravindo Persada;

[9] Hamzah, Evaluasi system penerangan jalan H.R. soebrantas kota pekanbaru, Telkomnika. 6(3): 199-208, 2008;

[10] Hau, Erich, Wind Turbin:Fundamentals, Technologies, Application and economic, (diterjemahkan dalam bahasa Inggris oleh: Horst Von Renouard), edisi ke-2, Springer: Berlin, Germany. 2005;

[11] I Gede Nyoman Suta Waisnawa, Analisis Resiko Investasi Pembangkit Listrik Tenaga Bayu Nusa Penida klungkung Bali, Tesis, Fakultas Teknik, Program Magister, Program Studi Teknik Sipil, Universitas Udayana, Bali, 2010;

[12] I Nyoman Pujawan, "Ekonomi Teknik", edisi Kedua Cetakan pertama, Institut Teknologi Sepuluh November, Penerbit Guna Widya, Surabaya;

[13] Muhaimin, 2001, Teknologi Pencahayaan, Bandung: PT. Refika Aditama;

[14] Peraturan Menteri ESDM No. 19, Tentang Pembelian Tenaga Listrik dari Pembangkit Listrik Tenaga Surya, Tahun 2016;

[15] Peraturan Presiden Republik Indonesia No. 5, Tentang Kebijakan Energi Nasional, Tahun 2006;

[16] Peraturan Presiden Republik Indonesia No. 61, Rencana Aksi Nasional Penurunan Emisi Gas Rumah Kaca (RANGRK), Tahun 2011;

[17] Pringatun, Sri, dkk. 2011. Analisis Komparasi Pemilihan Lampu Penerangan Jalan Tol. Media Elektronika, Vol. 4 No. 1, Juni 2011;

[18] Wiguna,IWayanY.M.,Ariastina,W,G.,Kumara,I,N,Satya. (2012).KajianPemanfaatanStandAlone

PhotovoltaicSystemuntukPeneranganJalanUmumdiPulauNu saPenida.Denpasar:Teknik ElektroUdayana;

[19] Youness, S., Claywell, R., and Muneer, T., (2005). Quality Control of Solar Radiation Data: Present Status and Proposed New Approaches, Amsterdam, Journal of Energi, Vol. 30, Issue 9, pp. 1533-1549.

[20] BMKG (Badan Meteorologi, Klimatologi dan Geofisika), 2015, Laporan Kecepatan Angin Rata - rata dan Persentase Penyinaran Matahari, Rahadi Oesman, Ketapang

[21] https://www.ketapangkab.go.id (Pemerintah Kabupaten Ketapang, 2017

\section{Biography}

${ }^{1}$ Erick Radwitya, lahir di Ketapang pada tanggal 08 Oktober 1985 putra pertama dari tiga bersaudara pasangan Amirudin dan Maisarah. telah menempuh pendidikan formal, antara lain di SD Negeri 06 Ketapang (Tahun 1991-1997), SLTP Negeri 1 Ketapang (Tahun 19972000), dan SMK Negeri 2 Ketapang (Tahun 2000-2003). Setelah lulus dari SMK tahun 2003, Penulis melanjutkan pendidikan di Politeknik Negeri Pontianak (POLNEP) mengambil program Diploma Tiga (D-III) Jurusan Teknik Mesin (Tahun 2003-2006), kemudian melanjutkan ke program Diploma Empat (D-IV) Politeknik Negeri Bandung (POLBAN) Jurusan Teknik Mesin, Program Studi Teknik Mesin Produksi dan Perawatan (Tahun 2007-2009). Pada akhir tahun 2012 Penulis melanjutkan pendidikan ke jenjang S2 di Program Magister Teknik Elektro Fakultas Teknik Universitas Tanjungpura dan terdaftar dengan NIM D0 1212 001. Penulis mengambil konsentrasi Manajemen Energi. Sejak tahun 2007 sampai dengan sekarang bekerja sebagai staf pengajar program studi Teknik Elektro di Politeknik Negeri Ketapang.

${ }^{2}$ Akhdiyatul, lahir di Ketapang pada 4 Mei 1984. Putra pertama dari tiga bersaudara pasangan Achmad Atasoge dan Sapiah. Telah menyelesaikan pendidikan formal, antara lain di SD Negeri 07 Ketapang (Tahun 1990-1996), MTs Negeri 1 Ketapang (Tahun 1996-1999), dan SMK Negeri 2 Ketapang (Tahun 2000-2003). Setelah lulus dari SMK tahun 2003, Penulis melanjutkan pendidikan di Politeknik Negeri Pontianak (POLNEP) program Diploma Tiga (D-III) Jurusan Teknik Mesin (Tahun 2003-2006), kemudian melanjutkan ke program Diploma Empat (D-IV) Politeknik Negeri Bandung (POLBAN) Jurusan Teknik Mesin, Program Studi Teknik Mesin Produksi dan Perawatan (Tahun 2007-2009). Pada akhir tahun 2012 Penulis melanjutkan pendidikan ke jenjang S2 di Program Magister Teknik Elektro Fakultas Teknik Universitas Tanjungpura dan terdaftar dengan NIM D0 1212 003. Penulis mengambil konsentrasi Manajemen Energi. Sejak tahun 2007 sampai dengan saat ini aktif bekerja sebagai staf pengajar program studi Teknik Elektro di Politeknik Negeri Ketapang. 